\title{
Reflections in the Field of Logistics Safety Stock Based
}

\author{
Wang Wei \\ Beijing Wuzi University, Beijing, China \\ Email: Wangwei199304@126.com
}

Received 24 May 2016; accepted 20 June 2016; published 23 June 2016

Copyright (C) 2016 by author and Scientific Research Publishing Inc.

This work is licensed under the Creative Commons Attribution International License (CC BY). http://creativecommons.org/licenses/by/4.0/

CC) (i) Open Access

\begin{abstract}
In the field of logistics and transport, safety stock has become an important part of establishing safety stock, which enables enterprises to predict demand which cannot be guaranteed; safety stock build is to improve service levels, and improves consumer the satisfaction, thereby enhancing the credibility of enterprises for corporate profits. However, the establishment of safety stock is bound to make the cost of business increase, after studies show that the safety stock in the logistics field cannot continue to increase down needs and logistics, logistics and speed limit orders supply chain into account, only in this way, the field of logistics safety stock is the most effective method of logistics.
\end{abstract}

\section{Keywords}

\section{Safety Stock, Logistics, Service Level}

\section{Introduction}

Safety stock is an important factor in every logistics companies that need to consider and solve enterprise security issues stock, and it can enable enterprises to accelerate capital turnover, improve service levels, and increase customer satisfaction, and companies in the industry's competitiveness will be strengthened. Therefore, research on the safety stock in today's logistics industry has an important significance. In real life, many researchers have become the logistics field of study and cannot be ignored in the process of commodity circulation, to some extent, the need for monitoring the implementation and management of commodity stocks. In order to make the enterprise level of service has been greatly improved, companies often increase their safety stock so as to satisfy customer orders in the maximum extent possible, so that it will also bring some problems, large customer orders increased, and it will enable enterprises to continuously improve inventory, increase the cost of doing business, and make corporate cash flow rate. A typical example is the tobacco conglomerate, and the annual demand for tobacco is very large, so companies have to have a lot of safety stock stocking for a rainy day. Countries need to unified coding for tobacco, and tobacco sale depends on the regulations of the state every quarter, to a certain 
extent, safety stock should meet the standards of the country or more than it. In the early development of logistics, many logistics companies, or warehouse distribution centers, storage of goods in order to increase their capacity, enable companies to provide the greatest degree of the goods to the buyer; it will create a stock, where the buyer is not just a common final consumers, and it may be logistics and distribution centers or warehouses of the local supplier of such trading relationship constituted consumer groups. This kind of safety stocks are provided just to satisfy service , but to the next stage, with the development of logistics, sometimes, many companies find that they establish inventories is the less amount of cargo, and it cannot meet the consumption needs of customers, after a long period in studying, we find that it is very important to propose that business must establish safety stock, this safety stock is different with that safety stock and it has different concepts, and safety stock is not simply to meet the needs of suppliers, in order to avoid a sudden increased demand or order and avoid the stock cannot meet the enterprise to be established, it can be called safety stock in this range. Such safety stock effect is obvious. We want to know, not only the safety stock by corporate financial constraints, what we called the cost, more importantly, the safety stock is also subject to the level of corporate supply chain, supply chain capabilities, the company's level of service and customer order requirements quantity is also an important factor. In general, the company's safety stock will be based on actual forecasts consumer orders over the years to see whether the order beyond reasonable than the need to build inventory safety stock. In addition, companies should have a good electronic information equipment and it can change the quantity goods of safety stock according to orders in a timely manner of control, once the need of goods is within or beyond a reasonable forecast range and it needs to prepare in time. It is worse that when the problem comes, workers do not know how to do it, and it is the problem of enterprise information management, but also it must result in decreasing customer satisfaction.

\section{Current Situation}

Many researchers have safety stock has done some research and analysis. Li Wu and Yue Chaoyuan (2008) two scholars of safety stocks in the supply chain were classified after comparison with inventory optimization model to optimize contrast, put forward the future development direction [1]. Wang Bo (2008) established the optimal safety stock model, and through the application of software and Excel model to calculate a safety stock [2]. Xin Hanyu and Liu Xiaowei (2004) two scholars from reality, proposed to consider the factors of safety stock from time to optimize the cost of direction for safety stock management made a very good prospects for the study [3]. Liugui Sheng (2008) according to the definition of safety stock, made at the time of the existing appropriate inventory levels, how to demand the maximum extent to meet the consumer's problem [4]. Jiang Aiping and Gao Junjun (2008) proposed a two scholars can solve non-core computer equipment suppliers delay in delivery of the phenomenon, to meet the requirements of safety stock. In summary, we can draw the majority of scholars have analyzed the factors affecting the safety stock are analyzed, but no security and supply chain inventory levels, and the level of service, limit orders on issues such as global thinking [5]. According to the literature we can know, safety stock analysis at home and abroad are directed at how to increase safety stock optimization, and did not take into account an optimal point optimization, optimization of safety stock is not just the relationship itself, but also, and corporate orders the amount of customer orders, the enterprise level of service, prior to scholars only from the surface to study the safety stock, and this article is to further the factors that affect the safety stock be optimized process to analyze the optimal safety stock.

Safety stock now exists many problems, first of all, domestic and foreign enterprises not systematically to consider the establishment of safety stock, just to meet the demand from a single point of view, a large area of the establishment of safety stock, waste of land resources and space layout, seriously affected the operational efficiency. Secondly, how much safety stock inventory is with increasing customer demand increases, which would take up a lot of money companies such lack of liquidity. Finally, companies do not have good electronic information equipment, orders for timely changes cannot control, once more than the reasonable needs or goods within the range forecast appears, cannot be ready solutions when the problem comes, I do not know how to do it, just to make enterprise information management problems, but also to customer satisfaction decreases. To solve these problems, this paper presents the view.

\section{Consideration of the Enterprise Safety Stock}

\subsection{Improve Supply Chain Level}

Existing companies should pursue to improve enterprise logistics supply chain level, the victory of enterprises 
have been converted from product quality to the level of the supply chain companies. Evaluation of the quality of the supply chain level indicator has two main aspects, one is out of stock level, which is what we commonly known as order fulfillment, customer placed an order, a company can quickly deliver goods to the customer depends on the company itself stock How much is the amount of goods or reserve safety stock, higher inventories of goods in the first time must be able to provide the required goods to customers, thereby increasing the level of out of stock, to further improve the level of the supply chain, and the other is inventory turns, business inventories can in a short period of time for the supply of goods and supply problems have a good convergence, directly determine the level of corporate supply chain. Therefore, enterprises should keep up with the logistics enterprises are now on the market, grasp the development level of the supply chain, supply chain logistics is an important part, only the enterprise supply chain well, do a good job, so that enterprises in the field of logistics the leading enterprises and competition. In addition, companies should learn from and the introduction of advanced logistics equipment and technology to ensure high-speed operation of supply chain level.

\subsection{Establish Temporality Stock}

The shortage risk results from the safety stock and reorder level differences, in other words, to prevent the enterprise customer orders exceeds the storage capacity of their goods, in order to maximize further meet customer demand, it is necessary to establish safety stock, the general extent, companies can accurately forecast customer demand through the calendar year, the predicted results of a detailed analysis, the statistics of customer demand for more than the average amount of inventory the enterprise itself, according to the average reasonable value data to establish safety stock to ensure that enterprises can meet the needs of customers. However, the establishment of safety stock cannot be rigid, static, should be able to expand the space, because customer demand is subject to change and may demand some products on a seasonal volatility, so for safety stock seasonal products on exhibit at high-low trend, the amount of safety stock of products will change. In summary, the establishment of safety stock of just how much demand for the product considering only the costs with the rapid development of technology and knowledge, and many enterprises have established safety stock enterprise itself and spent, borne by an enterprise risks, changes in the enterprise market, business product stability and volatility, etc., only considering these factors, in order to build a reasonable safety stock.

\subsection{Satisfaction Integration}

Enterprises will improve supply chain level after receiving more customer orders, with the improvement of customer orders, companies are bound to increase their security stocks, this approach is justified because although on the surface to increase customer orders, Buy people changed much, but his stock has increased, not only take a lot of inventory risk, commodity wastage and other issues, increased inventory costs make corporate cash flow rate also decreased for the development of enterprises is very Adverse. In order to improve the level of service, after the companies should choose a suitable safety stock limited customer orders as a maximum, to enable enterprises to improve the level of service will be traded in such a limit. This tells us that safety stock is not possible, safety stock belonging to fixed assets, safety stock, once completed, would like to change other purposes is very difficult. And safety stock must go through before they can be considered predictive of actual built much of the area is not possible, but to make too much capital turnover rate decreases, business activity will be greatly limited.

\subsection{Application of Management Information System}

21 century to 22 century of development, that must be an era of accelerating information technology, in the field of logistics, once out of the monitoring and management information, there is a business that will go a step away from death. The role of information management in large, grab information can observe the dynamic needs of consumers at any time, companies can timely for consumption analysis and practice based on the display information, the information for future development of enterprises and research there are non-negligible role. Strengthen information management, but also for the deployment of safety stock inventory and connection between the acts, when the stock shipping rates than the original storage, electronic information management device can send a signal to staff and timely, the timely transmission of information to security staff after seeing inventory management, management information according to user needs in the display, and timely delivery of 
goods to meet customer needs on time and in the product. A complete and timely information management system, will make the development of enterprises getting better.

\section{Summary}

Logistics safety stock is an important part of the enterprise that cannot be ignored, and improve the utilization of safety stock to grasp the consumer demand for their products change. The first is the enterprise to improve their supply chain level, customer orders within the next period of time which can be shipped in a shorter time, delivery, so that customers get their goods as soon as possible. Second, by improving supply chain level, the business is bound to establish safety stock of thinking and practice, implement selected after a reasonable amount of safety stock to further improve customer order fulfillment. Finally, the most important thing is that enterprise must remember to increase safety stock which is not unlimited and it is unable to build so large, the orders should be controlled within a certain range and it should be defined a reasonable scope. From that, enterprises are really enable to achieve service levels and improve the profitability or achieve their goals. Establishing safety stock determines whether the enterprise in the logistics field can speed up the pace of rate competition, determines whether the company's products logistics in time meet customer needs. Safety stock in the logistics field position is irreplaceable.

\section{References}

[1] Yue, C.Y., Li, W. and Chen, Y. (2008) Supply Chain Safety Stock Optimization Study. Natural Science (Central China Normal University), 4, 523-529.

[2] Wang, B. (2008) Safety Stock Optimization Methods of Modern Commerce Industry of Studying. Academic Journal, 5, 223-224.

[3] Xin, H.Y. and Liu, X.W. (2004) Time-Based Safe Stock Management. Commercial Research, 12, 71-72+111.

[4] Sheng, L.G. (2008) Safety Stock and Determine the Amount of Jiangsu Economic and Trade Vocational and Technical College. 4, 15-17.

[5] Jiang, A.P. (2014) Steep Stock-Based Security Policies to Improve the Rate of Orders Promptly Method. Industrial Engineering, 1, 80-86.

\section{Submit or recommend next manuscript to SCIRP and we will provide best service for you:}

Accepting pre-submission inquiries through Email, Facebook, Linkedin, Twitter, etc

A wide selection of journals (inclusive of 9 subjects, more than 200 journals)

Providing a 24-hour high-quality service

User-friendly online submission system

Fair and swift peer-review system

Efficient typesetting and proofreading procedure

Display of the result of downloads and visits, as well as the number of cited articles

Maximum dissemination of your research work

Submit your manuscript at: http://papersubmission.scirp.org/ 